\title{
醬油の褐 変
}

\author{
奥 原 章 Akira OKUHARA \\ キッコーマン醬油株式会社中央研究所
}

醬油の褐変色素は主としてメラノイヂン系に属すると いわれ，この色素を生成する反応をメイラード反応とい ら.メイラード反応は, 空気中の酸素による酸化を伴っ た酸化褐変と, 空気中の酸素が関与 しない非酸化褐変とにわけられ，醬 油の褐変にはこの両者が関与する. メイラード反応の初期と中期の段階 についてはかなり明らかにされてい る（図 1）が，実際に醬油中で起こ っている褐変反応はかなり複雑多岐 にわたっているので, 研究者により 知見の相異も生じている. 醇造物の 褐変については, 古くは黒野ら(1)の 研究があり, 醬油の色はメラノイヂ ン色素であるとし，大亦ら ${ }^{(2)}$ はこの メラノイヂン色素は糖とアミノ酸の 反応により生成したものであること， さらに, 酸化褐変はレダクトン類の 酸化物（デヒドロアスコルビン酸の ような化合物）がアミノーカルボニ ル反応を起こすためであること, エ ーテル可溶性カルボニル化合物が関 与している反応によって起こること， を報告している. 森口ら(3) は, 丸大 豆（普通の大豆）と脱脂大豆を原料 として用いた醬油の色沢の濃淡拉よ び褐変速度を検討し, 丸大豆を使用
した醬油のほうが色沢が淡く, 色沢の淡いほうが褐変速 度も小さいとし, 鎌田ら ${ }^{(4)}$ は, 味噌の無酸素状態の褐変 はペントースのみに関与し，グルコースは関係ないと報

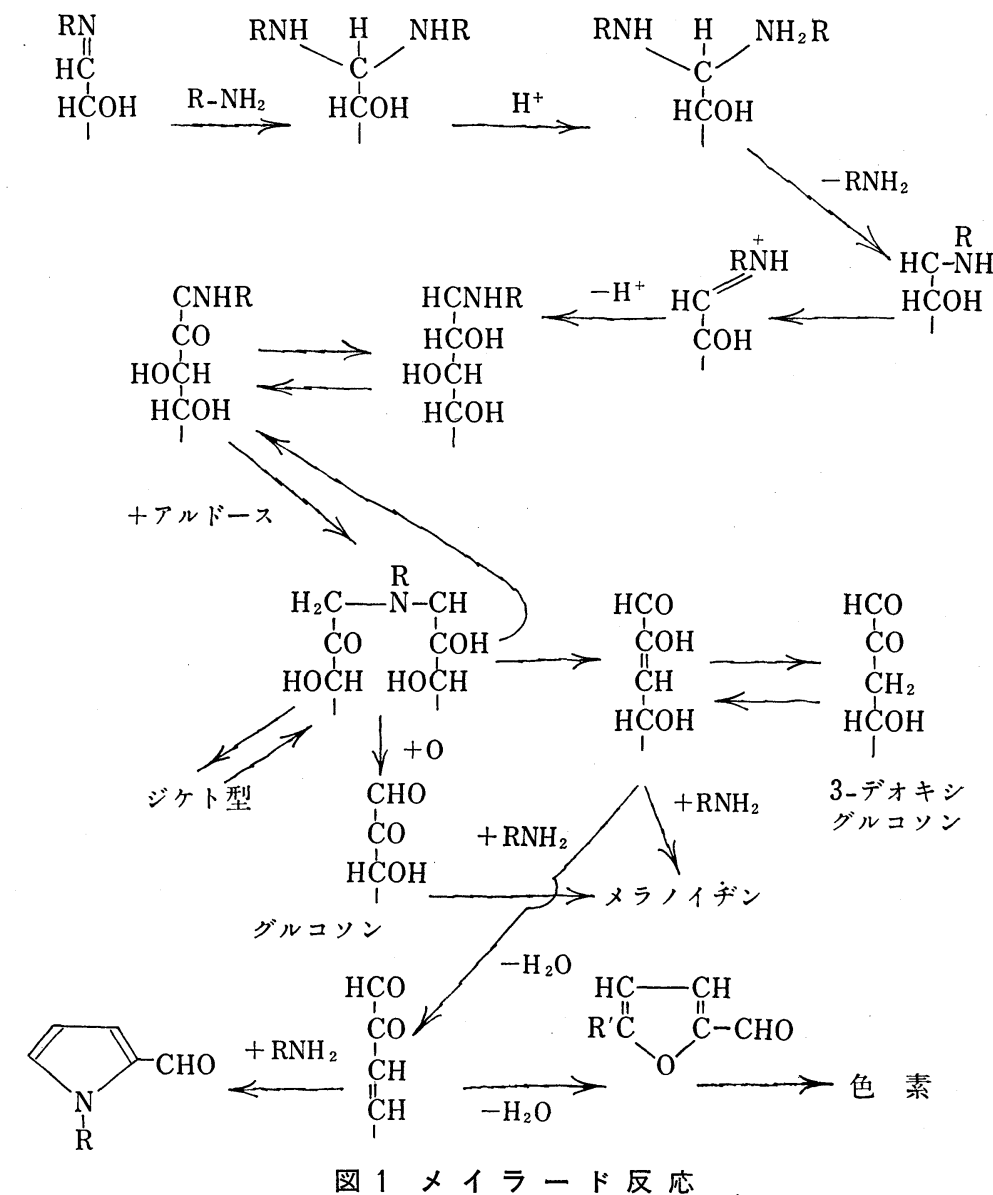

Vol. 10, No. 6 


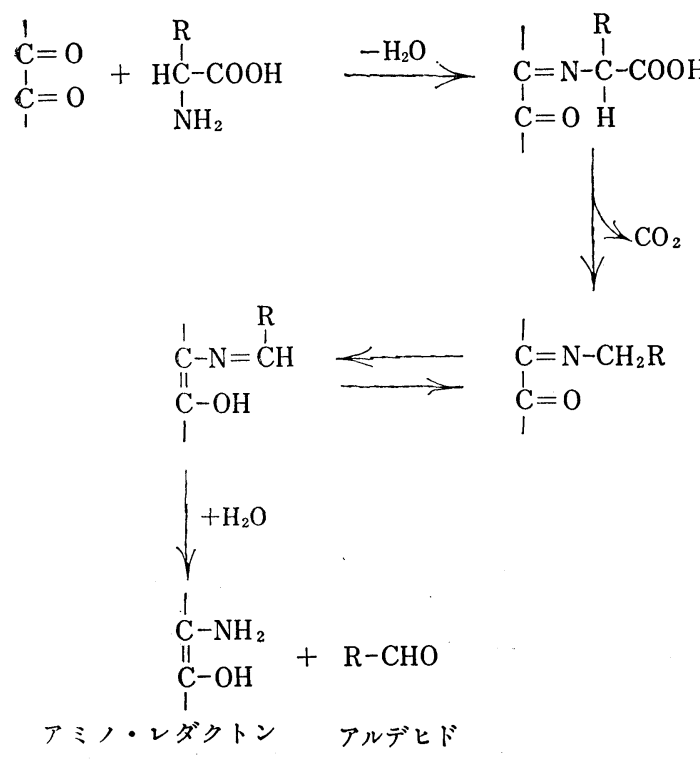

図 2 ストレッカー分解

告している. 加藤ら ${ }^{(5)}$ は, 醬油の褐変の中間体として 3デオキシグルコソンを認めて特り，岡ら ${ }^{(6)}$ は，清酒の褐 変で 3-デオキシグルコソンは全褐変量の 10～20\% しか 関与していないと報告している.

以上のように，褐变に関しての見解は研究者によりか なりの相異があり，グルコース（ヘキソース）もペント 一スも関与する，へキyースは関与せずペントースのみ が関与する，ヘキソースもペントースもわずかしか関与 せずほとんどが不明のものである，という3つの意見に わかれている，酸化褐変については，レダクトン類の酸 化物がアミノーカルボニル反応をすること，执よびェー テル可溶性カルボニルが原因であるとする 2 つ推論が あるのみである，糖とアミノ酸のモデル系の褐変に関し ては，加藤らによりグルコソン類を通る経路が明らかに されて打り，非酸化褐変飞比較して褐変速度が速いこと が知られている.

このほかに, やや高い温度 $\left(60^{\circ} \mathrm{C}\right.$ 以上) で反応がよく 進行するストレッカー分解がある.すなわち, メイラード 反応で生成したジヶトン類とアミノ酸が反応し，アミノ 酸は脱炭酸と酸化を受けて炭素数の1つ少ないアルデヒ ドとなる．これが醬油の火香(加熱殺菌工程で生ずる香) の一成分であるといわれている，一方，糖の誘導体は還 元されてレダクトン類になる（図 2).ここでいらレダ クトン類は次のようなもので, 2,6-dichlorophenolindophenol 還元性の物質である.
$-\mathrm{C}(\mathrm{OH})=\mathrm{C}(\mathrm{SH})-, \quad-\mathrm{C}(\mathrm{OH})=\left(\mathrm{NH}_{2}\right)-,-\mathrm{C}\left(\mathrm{NH}_{2}\right)=$ $\mathrm{C}\left(\mathrm{NH}_{2}\right)-,-\mathrm{C}\left(\mathrm{NH}_{2}\right)=\mathrm{C}(\mathrm{SH})-,-\mathrm{C}(\mathrm{OH})=\mathrm{C}(\mathrm{OH})-$

酸化褐変は, 矢の前駆物質以上飞酸素吸収力が強い(還 元性の強い）物質を添加すればある期間抑制でさるが， 非酸化褐変を抑制できる化合物は亜硫酸系化合物と, メ ルカプト系化合物ぐらいしか知られていない，両者と も，糖や糖の誘導体と反応して安定な化合物を作るため といわれている.

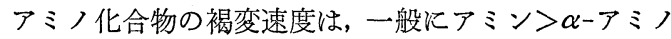
酸>ペプチドおよび蛋白の順であるといわれていたが， これを明確に検討した報告はないようである，糖類の褐 変速度は，リボース>キシロース>アラビノース>ガラ クトース>グルコースの順といわれている．筆者らは， 従来の定説（研究者により相違する点も多いが）が醬油 の褐变にどの程度当てはまるかを検討してみたので，以 下に紹介してみよう。

\section{1. 色彩（色知覚）上からみた徆油の色沢}

醬油の色沢は，すでに知られているように短波長側の 光の吸収が大きく長波長側で吸収が小さい、したがって， 色がうすい場合には淡黄色であるが，濃くなるに従って 橙色から暗赤褐色へと変化する．生醬油，火入醬油，拉 よび火入醬油を空気で酸化した醬油に食塩水を加えて希 釈し（たとえば濃度 0.1 は $10 \mathrm{ml}$ の醬油を $100 \mathrm{ml}$ に食 塩水で定容したものをさす), 色沢を $X Y Z$ 系で色表示 すると，表1〜3のようになる. 生醬油の濃度 $0.4(x=$ $0.568, y=0.419)$, 火入醬油の濃度 $0.2(x=0.569, y=$ $0.416)$, 拉よび酸化した醬油の濃度 $0.2(x=0.572, y=$ 0.416 を比較すると， $x, y$ の值は 3 者とる近いが， $Y$ (明度)の值は火入舾油 $(31.6 \%)>$ 生醬油 $(28.3 \%)>$ 酸 化した醬油（24.1\%）の順になった．醬油の色沢は火入 直後が一番良いとされているから，同じ $x, y$ の值のと きは $Y$ が大きいほど良いということになる。

醬油の変色には，この浪かに酸化褪色（色が淡くな る）といら現象があり，これは醬油が希釈され，空気に 触れたときに起こる，この場合，色調は赤味が消兄，Pe （刺激純度）が小さくなり，無彩色化してゆく，実際問 題としては調理後に変色が起こり，色彩が悪くなる．調 理直後は赤味のある淡い黄色に煮上っても, 時間ととも にしだいに赤味が消え, 極端にいうと青っぽい淡黄色に なって,ついには無色化してゆく。この酸化による褪色 
表 1 生醬 油の 色

\begin{tabular}{c|c|c|c|l}
\hline 醬油濃度 & $Y$ & $x$ & $y$ & $\mathrm{~m} \mu$ \\
\hline 0.1 & 66.9 & 0.453 & 0.434 & 583 \\
0.2 & 49.6 & 0.505 & 0.450 & 583 \\
0.3 & 36.8 & 0.547 & 0.428 & 588.3 \\
0.4 & 28.3 & 0.568 & 0.419 & 590.7 \\
0.5 & 23.5 & 0.586 & 0.402 & 593.8 \\
0.6 & 18.6 & 0.615 & 0.372 & 600 \\
0.7 & 15.7 & 0.617 & 0.374 & 599.5 \\
0.8 & 12.6 & 0.639 & 0.353 & 604.9 \\
0.9 & 11.3 & 0.647 & 0.350 & 605.5 \\
1.0 & 10.4 & 0.649 & 0.348 & 606 \\
\hline
\end{tabular}

表 2 火入醬油の色

\begin{tabular}{c|c|c|c}
\hline 醬油濃度 & $Y$ & $x$ & $y$ \\
\hline 0.1 & 53.3 & 0.489 & 0.415 \\
0.2 & 31.6 & 0.569 & 0.416 \\
0.3 & 21.3 & 0.596 & 0.396 \\
0.4 & 15.1 & 0.629 & 0.365 \\
0.5 & 10.8 & 0.648 & 0.336 \\
\hline
\end{tabular}

表 3 酸化した噌油の色

\begin{tabular}{c|c|c|c}
\hline 醬油濃度 & $Y$ & $x$ & $y$ \\
\hline 0.1 & 45.3 & 0.521 & 0.442 \\
0.2 & 24.1 & 0.572 & 0.416 \\
0.3 & 13.0 & 0.630 & 0.366 \\
0.4 & 6.8 & 0.678 & 0.303 \\
\hline
\end{tabular}

醬油を表記の濃度に希釈し，CIE（国際照明委員会）の XYZ 系であらわした. $x=\frac{X}{X+Y+Z}, y=\frac{Y}{X+Y+Z}, m \mu$ は主波長. 詳しくは, 色彩科学ハンドブック，色彩科学協会編，p.89を参照されたい.

現象は, 食塩濃度を上げても, また冷蔵庫中 $\left(5^{\circ} \mathrm{C}\right)$ に置 いても漸次進行し，防ぐことはできなかった．この現象 はアミノ酸液では少ないようであるが，この場合は初め から赤味が少なく嘫好上良くない, 結局, 調理後の食品 を保存するには空気と触れないように手早く包装するこ とがよい.

\section{2. 醬油の非酸化褐变}

\section{一空気中の酸素が関与しない褐変——}

初期のアミノーカルボニル反応生成物（図 1 参照）に, フェリシャナイド還元力を持っていることが知られてい る. 醬油にグルコースを添加し加熱すると, フェリシヤ ナイド還元力は増大するが, 褐変速度にはほとんど変化 がない.つをり,初期のアミノーカルボニル反応はある程 度起こるが，その先へに進行しないことを示している.

醬油にキシロースを添加すると褐変速度は大きくなる が, 醬油褐変にペントースが関与している割合をペント 一ス (キシャース) 消費量当りの褐変量から算出すると, 全褐变量の $10 \sim 20 \%$ である. 醬油をイオン交換樹脂で 処理してイオン化している物質を除き，これに糖類やポ リオール類を含む中性区分を調製して醬油に加えても， 醬油の褐変速度は少ししか速くならない。これは，一見 図 1 の反応に反するよらにみえるが，俆油の褐変は一定 温度では等速度であり，糖-アミノ酸のモデル系の褐変 速度は反応時間とともに速くなるので, 両者は反応の内 容が異なることを示している（糖-アミノ酸のモデル系

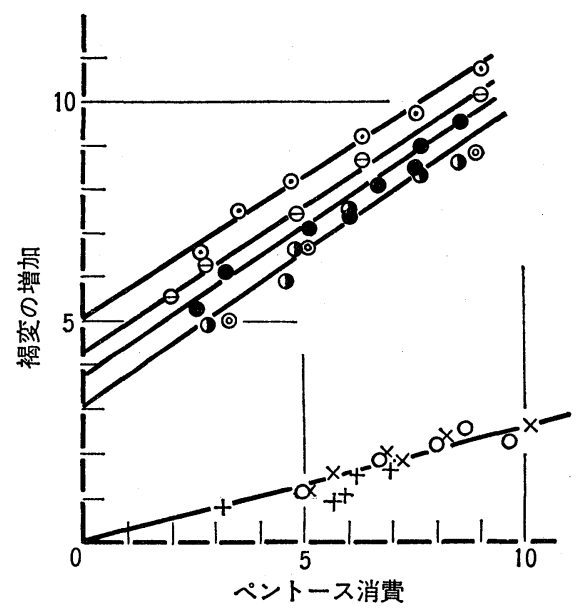

図 3 諸味液汁の褐変とペントース消費の関係(相対值) <諸味の経過日数> + : 1 週間, $x: 2$ 週間, $O: 1$ 力月, (): 2 力月, $(4$ 力月, -6 力月, $\ominus: 8$ 力月, $\odot$ : 10 力月

の褐変速度は，煪油に比較して極度に遅いため比較にな らない。この理由は後述する). 若い諸味液汁は褐変速 度が反応時間とともに大きくなるが，仕込後 3 カ月以上 を経ると, 熟成するに従ってしだいに醬油特有の等速度 形式になる，ペントースの消費を伴わない褐変量を図 3 から外插法で求めると, 仕込後 2 カ月目から急に増大 し, 以後は熟成とともに漸次増加した. 諸味液汁中のぺ ントース含量は, 仕込後 2 カ月くらいの間に $10 \mathrm{mg} / \mathrm{ml}$ 以上減少するが，ペソトースは諸味中で微生物に利用さ れずに褐変の中間体になっているのではないかと考觉ら 
れる、またペントースより生成した褐変の中間体が多 量に存在するため, 褐変の反応形式や速度がモデル系と 著しく異なると推測される.

非酸化褐変を賦活エネルギー $\left(E_{A}\right)$ から検討すると, 60 ${ }^{\circ} \mathrm{C}$ 以上では $E_{A}=27.9 \mathrm{kcal}, 50^{\circ} \mathrm{C}$ 以下では $E_{A}=16.9 \mathrm{kcal}$ であり，反応が多少異なることがわかる. $60^{\circ} \mathrm{C}$ 以上にな ると火香がつき，ストレッカー分解がさかんになること からも以上のことが想像できる.

よく熟成した諸味液汁のうちで, 残糖（諸味工程中に 発酵に利用されず残ってしまった糖）の諸味液汁は, 色 沢が濃厚で褐変しやすい. 生醬油の残糖と褐変速度の二 次相関は $r=0.688$ ( $1 \%$ 有意) であり, また生醬油の残 糖と色沢との間には $r=0.795$ ( $1 \%$ 有意) で一次相関が ある、このことから，残糖の主成分であるグルコースが 褐変の主要因であるようにも考兄られるが，正の一次相 関があるからといってただちに直接関係があるとはい えないむむら前述のように, グルコースは褐変にほと んぞ関与せず，したがって発酵のよくない諸味（以下， 諸味中でアルコールを多く生成し, 残糖の少ないことを 発酵がよいと表現し，その反対を発䤉がよくないまたは 発酵が悪いと表現する)，ないしは発酵を悪くする要因 を持つ諸味からの生醬油は, 褐变速度が速いと解釈すべ きである、それでは, 発醳のよい諸味はなぜ色沢が淡く 褐変速度が小さいのであろらか.

\section{3. 還元による褐変色素の脱色と褐変の抑制}

諸味中では，酵母の作用によりグルコースがマンニト 一ルやエタノールに還元されることなどから，巨視的に みればきわめて還元的な状態にあるといえる．この間に その他の物質も還元されるから, 褐变の中間体も直接あ るいは間接的に酵母の作用で還元され, 褐変しない物質 飞変化するのではないかと考觉られる.

亜硫酸, メルカプト化合物（システイン,メルカプト酢 酸など)はアミノーカルボニル反応を阻止するが，いずれ も強い還元力を持って扣り，とくに亜硫酸塩は醬油中の 糖のモル濃度より少し低い濃度で醬油の褐变を完全に阻 止する.この注か，アスコルビン酸を醬油に添加すると， ただちにその 8 割以上が消失し, しかも非酸化褐変は著 しく抑制される.褐変速度は $1 \%$ の添加で対照の約 0.65 飞なるが，それ以上添加量を増加すると，対照の 0.5 近くに漸近した. しかも, アスコルビン酸により還元さ
れた醬油の褐変形式は醬油独特の等速度形式であった。

以上のデータは，非酸化褐変も還元により抑制される ことを示している，醬油にアルミニウム，亜鉛などの金 属粉を添加すると醬油は徐々に脱色され，この現象は醬 油ばかりでなく $\mathrm{pH}$ が酸性の他の食品に执いても認めら れた。これは，金属が溶解するときに放出する電子によ って，褐変物質が還元され脱色されるためである，金属 による還元の前後では褐変速度に変化はなく, 脱色はさ れても褐变速度は抑制されなかった。

金属を用いて液体食品の酸化や褐变を防止するには, 金属と液体食品を接触させるのみでよく，しかも効果の 持続時間が長いので, ビン詰, 罐詰などのいわゆる包装 食品の酸化や褐変の防止に有効である. とくに，アルミ ニウムがこの目的に適している. プラスチック容器は, 微量ではあるがガス透過性があるので効果が強く現われ る(表 4).

還元剤による還元では, 醬油中に溶存した還元剤の酸 化物を除去することが難しい，たとえば，アスコルビン 酸で睘元したときは，デヒドロアスコルビン酸の影響を 無視できない，そこで，陰極から電子を供給して還元す る電解還元法で実験を行ない, 還元剤の酸化物の影響を 除いた，装置は図 4 亿示したものを用いた．醬油を酸性 （pH 4６）で電解還元すると，脱色はされるが，褐変 速度はわずかしか小さくならない。录た，脱色と同時に 数 $10 \mu \mathrm{g} / \mathrm{ml}$ (アスコルビン酸換算) のレダクトン類が生 成する、これは, 招そらくレダクトンの酸化型が一部還 元されてレダクトンに再生するのであろう. 生俆油の場 合, 約 $1 / 2$ の吸光度にまで脱色することができる. 醬油 にアルカリを加えて $\mathrm{pH}$ を中性ないしアルカリ性で電解

表 4 アルミニウムによる褐変防止

\begin{tabular}{c|c|c}
\hline $\begin{array}{c}\text { ポリスチレン濃度 } \\
(\%)\end{array}$ & $\begin{array}{c}\text { 吸 光 } \\
(500 \mathrm{~m} \mu)\end{array}$ & 色 沢 番 号 \\
\hline 0.1 & 0.770 & 6 \\
0.2 & 0.774 & 6 \\
0.4 & 0.790 & 6 \\
0.8 & 0.796 & 6 \\
1.5 & 0.802 & 6 \\
2.0 & 0.812 & 6 \\
対 照 & 0.864 & 3 \\
\hline
\end{tabular}

ポリビニルクロライド $500 \mathrm{ml}$ 容器の内面にアルミニウム 塗料（表に示した濃度のポリスチレン酢酸エチル溶液中にア ルミニウム粉末を $2 \%$ に懸濁した） $0.5 \mathrm{ml}$ を塗装し，火入 醬油を詰め $30^{\circ} \mathrm{C} に 40$ 日静置した. 火入醬油の初発色沢濃度は 0.784 


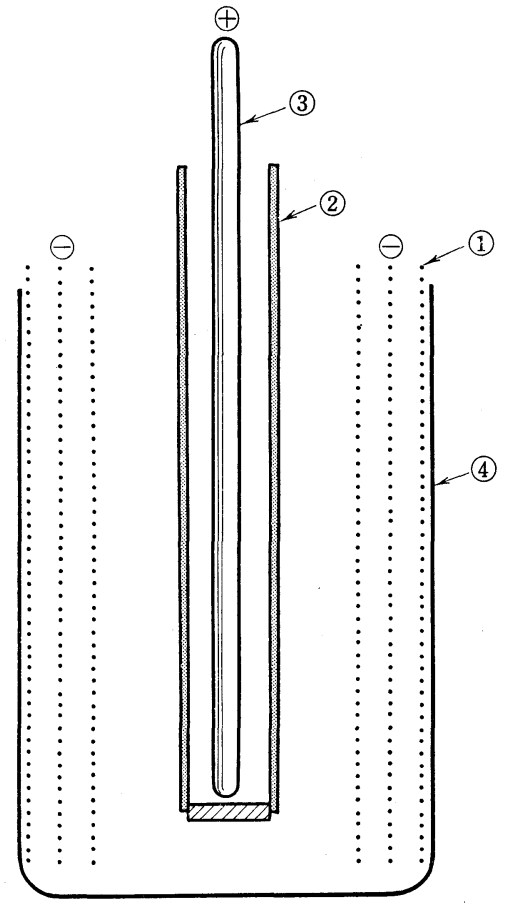

図 4 電 解 還 元 槽

(1) 陰極，アルミニウム網または鉛アマルガム. (2) 陽極室 容器, 素焼パイプ. (3) 陽極, カーボン棒. (4) 電解槽容器, $2 l$ ビーカー.

還元すると，褐変速度は元の醬油の $80 \%$ くらいに減少 するが，糖類は還元されなかった，つ委り，諸味工程中 では，発酵により還元状態に保たれているので褐変速度 が小さくなるのである．前述のように，醬油にアスコル ビン酸を添加するとほとんどが消失するが，消失したア スコルビン酸は中性ないしアルカリ性で電解還元しても 再生しないので, 電解還元はアスコルビン酸の還元より 弱いと考えられる。

電解還元した醬油を加熱すると、レダクトン類はいっ たん減少してから増加する．アスコルビン酸を添加し， さらに電解還元を中性ないしアルカリ性で行なった醬油 は， $80^{\circ} \mathrm{C}$ に加熱するとレダクトン類は初めの 1 時間く らいは急速に減少し，その後はほぼ一定になってし末う。 対照の醬油でも, 加熱の初期 $\left(80^{\circ} \mathrm{C}\right.$ 加熱の場合は 2 時間 くらいまで) はレダクトン類の増加が遅かったり，ある いは少し減少してから増加する. そして，加熱中に褐変 速度の遅い醬油は初期のレダクトン類の減少が大きく， その後の生成量も少ない(図 5). 筆者の想像では, レダ クトン類は 2 つのグループ, すなわち, 加熱により減少 するグループと，加熱（褐変）により生成するグループ

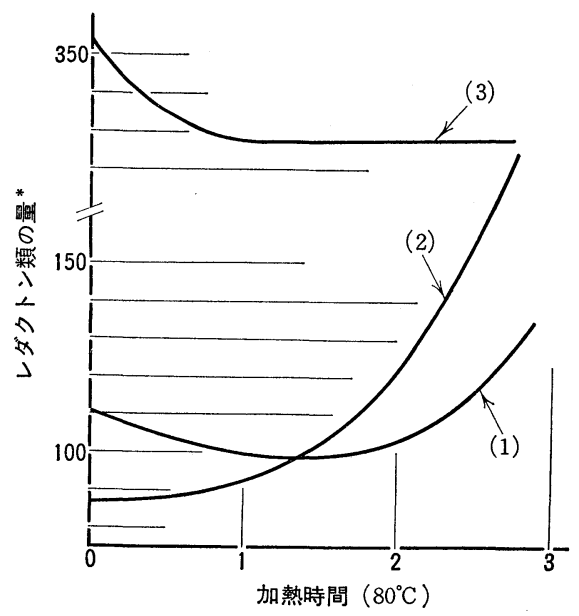

図 5 醬油の加熱とレダクトン類の消長

（1）対照俆油，（2）中性〜アルカリ性で電解還元した俆 油,（3）アスコルビソ酸 $1 \%$ 添加後, 中性〜アルカリ性で 電解還元した醬油

とにわけられ，加熱で減少するレダクトン類が多いほど 褐变速度が遅いのではなかららか.

醬油の $\mathrm{pH}(4.8)$ でも，電解還元中は褐变反応が抑制 されていると思われる. $70^{\circ} \mathrm{C}$ に加温しながら電解還元 すると,色沢から見た褐変量が少ないばかりでなく、レダ クトン類の生成も少ない（電解還元で脱色されるとレダ クトン類は少量増加しても減少はしない)，還元で褐変 速度を遅くした試料も，対照と同様に加熱によりペント 一スが減少する.したがって, 還元により初期のアミノー カルボニル反応は抑制されず，褐変の中間体が還元され ることにより褐変色素にならないと考えられる。電解還 元法では, メラノイジン色素は脱色できるが，カラメリ ゼーションによる色素の脱色は難しい，また，脱色速度 は招特む称電流飞比例的である。

\section{4. ペプチドの褐变}

醬油の褐変速度が速いのは，長い醸造期間を経ている ために褐変の中間体が充分に存在するといら理由はあっ ても, 糖とアミノ酸のモデル系に比較してあまりにも速 い, 筆者らは, 多くのデータから, 非アミノ態窒素の多 い生醬油は, 色も濃く褐変速度も速いように考觉ていた が，他の要因もあってきわめてあいまいであった，非ア ミノ態窒素 $(\mathrm{TN}-\mathrm{FN}) *$ の多い醬油はほとんどの場合に 発酵が悪く, 非アミノ態窒素が発酵を阻害するために褐

\footnotetext{
*総案素 $(\mathrm{TN})$ からフォルモール窒素 $(\mathrm{FN})$ を差し引いた值.
} 
変速度が速くなるのか，非アミノ態窒素が褐変しやすい のかまったく判断しかねた。 とくに，蛋白やペプチド はアミノ酸に比較して褐変速度がきわめて遅いかのよう にいわれているため，いっそう発酵阻害物としてのみ作 用すると思われた，文献を参照してもペプチドとアミノ 酸の褐変速度を明確に比較した例は見あたらなかったの で，非アミノ態窒素区分の検討を行なった．

醬油中には非アミノ態窒素区分以外に多くの成分が存 在し、これらを分離することは非常に難しい。そこで, 大豆蛋白を蔡菌（Aspergillus sojae）の酵素（プロテア 一ゼ）で加水分解し，非アミノ態窒素区分の多い蛋白分 解液を調製し，これにキシロースを $1 \%$ 添加して加熱し たところ，急速に褐変した．同様にして醭素剤の褐变も 測定したが, 微量であったため, 蛋白が醭素により分解さ れることにより褐変速度の速い物質が生成すると判断さ れた。 この蛋白分解液に三塩化酰酸を $10 \%$ 加兄て蛋白 を除いたペプチド液 $(\mathrm{FN} / \mathrm{TN}=0.28)$ は，前述の条件で よりいっそう褐变速度が速くなった. Sephadex G-25を 用いペプチド液より FN の一部を吸着除去した液 (FN/ $\mathrm{TN}=0.24 ）$ は，同一の条件でいっそら急速に褐変した （すべての試料には食塩を $20 \%$ 加兄，濾過した後 $\mathrm{TN}=1$, $13 \%, \mathrm{pH} 4.8$ 亿調整した液を $80^{\circ} \mathrm{C}$ 飞加熱して褐变させ て比較した)，以上のデータは,ペプチド区分が濃縮され るほど褐变速度が増大することを示している，そこで， ペプチド標品と $1 \%$ のキシロースを含む液（pH 4.8）を $80^{\circ} \mathrm{C}$ に加熱して褐変速度を比較した（表 5). ペプチド 標品はモル比で示すと, それぞれのアミノ酸の実に約 20 倍から 50 倍強の速さで褐変した.ペプチド液も非アミ ノ態窒素換算で, アミノ酸の 20 倍以上の速さで褐変し， ペプチド類がアミノ酸に比較して桁はずれに褐変速度の 速いことが明らかとなった。

しかしながら、ここに調製したペプチドが醬油中にも 存在することが明確にならなければ, 醬油の褐変速度が ペプチドによると判断するわけにはゆかないので，次に その点について検討した.

まず，醬油のペプチドとペプチド液のペプチドとの分 子量分布を Sephadex G-25 カラム（長さ $150 \mathrm{~cm}$ ) によ るゲル滤過法で比較した．溶出は $0.2 \mathrm{M}$ 酢酸緩衝液 $\mathrm{pH}$ 4.8 で行ない，溶出液はアルカリ分解後ニンヒドリン発 色を行なった。醬油とペプチド液の溶出パタ ンは近似 して打り，ペプチド分布の中心は，アラニンのペプチド
表 5 ペプチドの褐変

\begin{tabular}{lc}
\hline ペプチドまたはアミノ酸 & 吸光度 $(500 \mathrm{~m} \mu)$ \\
\hline Glycine & 0.0166 \\
Glycylglycine & 0.459 \\
Glycylglycylglycine & 0.658 \\
Glycylglycylglycylglycine & 0.854 \\
$\alpha$-Alanine & 0.0166 \\
$\alpha$-Alanylalanine & 0.2798 \\
\hline
\end{tabular}

ペプチドやアミノ酸を，キシロース $1 \%$ を含む $0.2 \mathrm{M}$ 酢酸緩 衝液 $\mathrm{pH} 4.8$ に $0.1 \mathrm{~m}$ 濃度に溶解し, $80^{\circ} \mathrm{C}$ に 5 時間加熱した.

に換算してアミノ酸残基 $3 \sim 4$ くらいのペプチドのよう である。

次に, CM Sephadex C-25, $160 \mathrm{ml}$ のカラムにより, 醬油とペプチド液のクロマトを行なった，溶出液は 0.2 $\mathrm{M}$ 酶酸緩衝液 $\mathrm{pH} 4$ ～8 で, 前述のようにニンヒドリン 発色をしたところ，醬油のクロマトグラムとペプチド夜 のそれは近似していて，3つの区分にわかれた，溶出の 早い区分から I，II 叔よび且とすると，区分 I は褐変色 素であり,区分II と正はニンヒドリン発色が強く, 褐変し ていない.これら区分 I，II特よび吕を別々に G-25 カラ ムでダル濾過すると，区分 Iは他の 2 つの区分に比較し て分子量が大きく，区分II と正は同じ分子量分布であっ

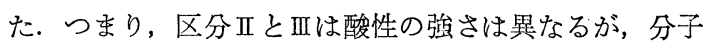
量的には同じ範囲に入るペプチド区分である，以上のよ うに，醬油のペプチドとペプチド液のそれは，分子量的 にも酸性の程度からも同じであることが認められ，ペプ チド液での実験の結果は醬油にあてはめても良いことが 確かめられた.

さらに, 前述の CM Sephadex C-25 カラムとよるク ロマトの区分 I，III特よび且は，キシロースを $1 \%$ 添加 して加熱すると，いずれもぺプチドが褐変（褐変色素区 分はわずかしか褐変しなかったが）していることを確認 した。

以上のデータから, 輏油の褐変が糖-アミノ酸のモデ ル系に比較して非常に速い理由の 1 つとして, 醬油中に は多くのペプチドが存在し, これらの褐变速度が非常に 速いためと結論される。 また，味淋，酒からも区分II拉 よびIIIのペプチドが少量検出されたので, 酒類の褐変の いくらかはペプチドによるのかもしれない.

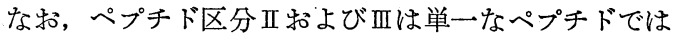
なく, Dowex カラムで分画すれば,ささらに多くのペプ チドに分画される. しかし, 特定のペプチドのみが褐 変しやすいのではなく，多くのペプチドについていえる 
ことである. これらのペプチドはニンヒドリン反応陽性 で,アミノ末端特よびカルボキシル末端のアミノ酸も存 在する.

\section{5. 酸 化 褐 変}

ここでいら酸化褐変は, 火入醬油（加熱殺菌した醬油） が空気に触れたときに色が黒ずむ現象であり，3-デオキ シグルコソンを通らずグルコソン類を通るモデル系の褐 変とは意味がちがう。この反応は, 常温で急速に進み, さらに都合の悪いことに, 前述のごとく酸化褐変は非酸 化褐変と色調が異なるため, 吸光度ではわずかな変化で も肉眼的にはかなり大きな差として感ずる.

醬油の酸化褐変量は, 酸化する前の初発色沢濃度に比 例的であった. 火入温度が変わっても，また同一の原料 配合で作つた多くの醬油（TN 濃度を調整して, 非酸化 褐変速度の速いものは短時間, 遅いものは長時間加熱し て同一色沢濃度に調整した）も，酸化褐変量は等しかっ た. しかし, 非酸化褐変で生成した褐変色素が酸化され て, 吸光度が大きくなっているのではない.すなわち, 醬油を $80^{\circ} \mathrm{C}$ に $1,2, \cdots \cdots 5$ 時間加熱した試料（対照）群 そ, 5 時間加熱の試料に活性炭を $0.5,1.0, \cdots \cdots, 2.0 \%$ 加兄て脱色し初発色沢濃度を調整した試料群とを酸化褐 変させると, 両試料群とも初発色沢濃度に比例的に酸化 褐変量は増大するが, 活性炭脱色の試料は対照に比較し て初発色沢濃度よりも酸化褐変量が大きかった．同様の 実験をくりか兄して, 初発色沢濃度 $(x)$ と酸化褐変速 度 $(y)$ との関係を求めると, $y=a x+b$ の一次式で表わ される. この式から, 対照は $a=0.028$, 活性炭処理は 0.023 となり， $x$ と関係が少なくなった. また，1つの 生醬油を加熱して種々の色沢濃度に調整した試料は, 初 発色沢濃度と酸化褐変量との関係が正確に一直線上にの るが，TN 濃度の異なる多くの醬油を非酸化褐変させ， 初発色沢濃度と酸化褐変量との関係を求めると, 相関係 数は 0.439 と小さくなる.したがって，非酸化褐変で生 成した褐変色素の吸光度が変化するのではなく，非酸化 褐変と比例的に生成する未知物質が空気に触れると, 酸 素で酸化されて黒っぽい色を生成すると解釈される，非 酸化褐変と異なり, 発酵やペプチドとは直接的には関係 ない.

酸化褐变が酸素吸収を伴らことはいらまでもないが， 褐変量は酸素吸収量に比例しない, 酸化褐変は初めのう
ら急速に進み，しだいに速度が減少し，ついには等速度 になってしまう，酸化褐変はきわめて急速に起こるので, 初めのらちは非酸化褐変などで生成し蓄積した前駆物質 が反応して急速に褐変し，その後は非酸化褐变などによ り生成する前駆物質をそのつど酸化褐変するので, 等速 度になるのであろう．酸化褐変の初期の反応をみても， やはりごく初期は急速であり，酸素吸収速度も大きいが， 短時間のうちに褐変速度は小さくなる. そして, 褐変が ほとんど進まなくなっても（1 時間おきの吸光度の増加 がきわめて小さくなっても)，酸素吸収はごく初期を除 いてはほぼ等速度で行なわれた。. 火入醬油の容量に対す

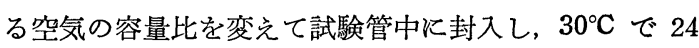
時間振盪すると, 空気量に正確に比例してレダクトン類 は減少したが, 酸化褐変量は空気量の少ない汪う（容量 比で 0.4 以下）では空気量の増加とともに褐変量も増大 した. しかし, それ以上空気量を多くしても褐変は進ま なかった

また, 大亦らにより,レダクトン類の酸化物がアミノー カルボニル反応を起こすのが酸化褐変ではなかららかと 提唱されているので, 火入醬油 $\left(80^{\circ} \mathrm{C}, 5\right.$ 時間) に室温

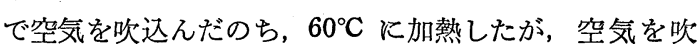
込んだものは対照より褐変速度が小さかった。したがっ て，前述の酸化しても褐変しなかったレダクトン類があ とになつて褐変することはない,つまり,褐変に関係のな いレダクトン類も多く存在することになる。しかしなが ら, 醬油中のレダクトン類の量と酸化褐変量とは比例的 である.したがって, 非酸化褐変により酸化褐変するレ ダクトン類が，全レダクトン類中の何\%かの一定の比率 で生成するのであろう，そして，空気に触れると顕著に 褐変するレダクトンから先に酸化されれると考えられる.

次に, 火入醬油のエーテル可溶性の中性部について, エーテル可溶性カルボニルの酸化褐変への影響を検討し たが，筆者らの方法では影響はなかった：酸化褐変は， 食塩濃度が $20 ， 15 ， 10 ， 5 \%$ と低くなるに従って速くな る傾向がある.レダクトン類の 1 つであるアスコルビン 酸は, $\mathrm{Cl}^{-}$濃度が高くなると酸化が防止される傾向のめ ることが知られて拈り (7)，执とらくこの場合も $\mathrm{Cl}^{-}$の影 響であろち。

\section{6. 重回帰分析による褐变機構の解析}

上記の研究結果が，実際問題とよく当てはまるかどう 
かを統計的に検討する目的で重回帰 分析を行なった．表 6 亿褐変と関係 のある成分または要因を揭げた.

一次相関が有意な成分は多いが， 偏相関が有意な成分は少ない，生醬 油の色沢濃度や非酸化褐变には, 非 アミノ態窒素 (TN-FN) 区分と RS (RS が多いのは発酵が悪いことを意 味する）が大きく関与している．酸 化褐変にはレダクトン類の酸化量と Bê が関与しているが，Bê は特定の 成分ではなく可溶性固形物濃度が高 くなると，酸化褐変も大きくなると 解釈される，また，レダクトン類は 同時に酸化褐变を抑制しているが，

酸素を吸収し抗酸化的にも働くため であろう，食塩の酸化褐变抑制効果 は少し現われているが，酸化裉色と 成分との関係は不明であった，以上 のことから，今までのべた § 1〜 5 の推論や結論は実際の現象とよく合 らことがわかる.

\section{文献}

1）黒野勘六，勝目英：農化，3，594 (1927); 黒野勘六, 深井冬史, 飯 野正淳：農化, 3, 1193 (1927); 黒野勘六, 深井冬史 : 農化, 3, 1291 (1927).

2）大亦正次郎, 上野照雄 : 農化, 27 , 571,575 (195\&) ; 大亦正次郎，上 野照雄, 中川泰：農化, 29, 165, 215, 251, 256 (1955)； 大亦正次郎, 上野照雄, 中川泰: 醗工, 34, 166 (1956).

3）森口繁，石川浩：酘工，38，271，413，418 (1960).

4）鎌田栄基, 海老根英雄, 中野政弘 : 食品工業学会誌, 9, 233 (1962) ; 鎌田栄基, 桜井芳人：調味科学, $11 ， 21$ (1964).

5）加藤博通, 山田靖宙, 井坂健一, 桜井芳人: 農化, 35, 412(1961); 加藤博通, 桜井芳人：農化, 37, 423(1963)； 加藤博通, 桜井芳人: 醗工, 36, 131 (1961).

6) 岡 智: 酸工, 44, 628 (1966).

7）松下雪郎, 岩見舒子, 新用ゆき：農化， 41,77 (1967); 一瀬義文: 栄養と食糧，7，221（1950）; 宮本貞一：共立 薬大報, 4, 7 (1958); 山名月中, 太田次作: 薬剤学, 21, 32 (1961); 住木諭介, 林広 : 化学々生物, 23, 1 (1949).

<その他の交献>

奥原章, 原田倫夫, 斎藤伸生, 横塚保 : 躌工, 47, 50 (1969); 奥原章, 中島隆, 田中輝男, 斉藤伸生, 横塚保: 醱工, 47, 57 (1969); 奥原章, 斉藤伸生 : 醱工, 48, 177, 190 (1970); 奥原章，田中輝男，斉藤伸生，横塚保：醴工，48，228 (1970) ; 奥原章, 斉藤伸生; 横塚保 : 醱工, 49, 272 (1971).
表 6 褐変に有意に相関する成分

\begin{tabular}{|c|c|c|c|}
\hline $\mathrm{C}(\mathrm{H}-\mathrm{F})$ & $\mathrm{C}(\mathrm{OX}-\mathrm{H})$ & $\mathrm{C}(\mathrm{H}-\mathrm{N})$ & $C(N)$ \\
\hline$*$ & $\begin{array}{c}* * \\
* * \\
* \\
(++) \\
*\end{array}$ & $\begin{array}{l}* * \\
* * \\
* * \\
* *(++)\end{array}$ & $\begin{array}{l}* * \\
* * \\
* * \\
* *(++)\end{array}$ \\
\hline$(-)$ & $\begin{array}{l}* \\
* \\
*\end{array}$ & $\begin{array}{l}(+) \\
* \\
* *(+) \\
* *(++)\end{array}$ & $\begin{array}{l}* \\
* *(+) \\
* *(++)\end{array}$ \\
\hline$*$ & $\begin{array}{l}-* * \\
\\
-* * \\
*(+) \\
-* *(--) \\
* *(++)\end{array}$ & $\begin{array}{l}-* * \\
-* \\
\\
* * \\
* \\
\\
\\
* *\end{array}$ & $\begin{array}{r}-* * \\
-* * \\
-* * \\
-* * \\
* *\end{array}$ \\
\hline & $\begin{array}{l}-* *(-) \\
* \\
* \\
* *\end{array}$ & $* *$ & \\
\hline
\end{tabular}

$*$ 一次相関 （十）または (一)は扁相関が $5 \%$ 有意. $(++)$ または (-ー) は扁相関が $1 \%$ 有意. 胀量, WK：原料単位当りの数重量, 1：原料単位当りの液汁（生醬油）

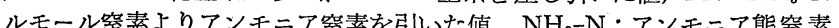
: 滴定酸度, $\mathrm{RS}$ : 残糖, Org-Acid : 有機酸量, $\mathrm{pH}$ : 生艘油の值, $\mathrm{RN}$ : 生醬

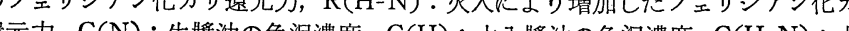
生醬油のレダクトン類含量, $\operatorname{Red}(\mathrm{H}-\mathrm{N})$ ：火入で増加したレダクトン類量, $\operatorname{Red}$ $(\mathrm{H}-\mathrm{OX})$ : 酸化で減少したレダクトン類量である.

\section{第 4 回 生命科学パネル討論会}

日 時: 1972年 7 月 8 日(土) $1: 30 \sim 5: 00$ p.m 場 所: サンケイ国際ホール (サンケイビル 5 階) 千代田区大手町 1-7-2 (Tel) 231-7171 テーマ:「生命科学と情報科学」

出席者: 伊 藤 貴 康 (三菱電機中研, 人工知能) 小関治男.(京大・理, 分子遺伝) 北川敏男 (九大・理, 情報科学) 桑原万寿太郎（九大・理, 動物生理) 島 津 浩 (東大・脳研, 神経生理) 樋渡滑二(NHK・技研, 感覚情報) 吉田夏楌 (東工大, 哲学)

司 会: 南雲仁一 (東工大·工, バイオニクス)

主 催: 三菱化成生命科学研究所

千代田区丸の内 2-3-1

(Tel) 212-6411 (内線 2110)

污多数の方の御来聴を歓迎致します. (入場無料)

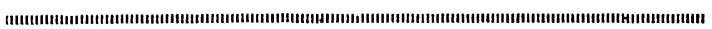

